\title{
DO ESPAÇO AO LUGAR: UMA APROPRIAÇÃO VISUAL DO BAIXO CENTRO CULTURAL
}

\author{
Manoela Tarcila Martins Rosa \\ Universidade do Estado de Minas Gerais \\ manoela.tarcila@gmail.com \\ Rosilene Conceição Maciel \\ Universidade do Estado de Minas Gerais \\ rmaciela@gmail.com \\ Rita de Castro Engler \\ Universidade do Estado de Minas Gerais \\ rcengler@uol.com.br
}

Resumo: Sob as mais variadas formas, as manifestações artísticas vêm deixando suas marcas no cotidiano urbano. Este trabalho apresenta resultados parciais de um projeto de extensão que visa identificar, registrar e difundir essas intervenções ao longo da Rua Aarão Reis, que compõe uma região reconhecida como "Baixo Centro Cultural" da cidade de Belo Horizonte. Na localidade em questão, há um movimento de apropriação do espaço urbano, que está sendo investigado com a finalidade de entender $\mathrm{e}$ debater as narrativas expressas pelas intervenções gráfico-visuais constantes no local. A rua foi escolhida como local de estudo por se tornar palco de grandes manifestações políticas, culturais e artísticas ao longo da última década. Dentro desse contexto, há uma construção da identidade desse território de domínio público pelos seus frequentadores, que por sua vez, tornam-se usuários de um espaço multicultural e agentes ativos na transformação da paisagem. Para o desenvolvimento da pesquisa foram realizados registros fotográficos em campo, para posterior análise e publicação em plataforma colaborativa. A revisão bibliográfica vem sendo realizada em paralelo de forma a fundamentar o trabalho de campo. Foi realizado um levantamento histórico sobre as mudanças físicas e estruturais que propiciaram a atual contextualização da apropriação da região, mostrando-se relevante para entendimento e compreensão das transformações ocorridas ao longo dos últimos anos. Por meio de reconhecimento de campo, foi possível determinar o recorte a ser trabalhado e identificar de que forma as intervenções estão situadas para melhor delimitar o estudo. Uma sondagem preliminar com comerciantes locais e transeuntes possibilitou obter informações sobre eventos, frequentadores e usuários, do ponto de vista daqueles que fazem parte do cotidiano da localidade. Na primeira visita a campo, foram feitos os registros fotográficos iniciais, determinantes para um reconhecimento dos territórios existentes e tipologia das imagens. Na sequência, estão sendo realizados registros periódicos que visam um acompanhamento da 
movimentação gráfico-visual na paisagem local a partir de estudos comparativos. A proposta final é a construção de um acervo que possibilite acesso, conhecimento e compreensão dessas manifestações artísticas e viabilize desdobramentos de estudos acadêmicos e ações investigativas nesse campo. Sendo este alicerçado nas reflexões acerca da relação entre arte urbana e espaços públicos e nas análises dos elementos simbólicos presentes nas intervenções.

Palavras-chave: Intervenção urbana, cultura, arte, design, Belo Horizonte 